\title{
Analysis of Students' Needs Related to their Learning Preferences
}

\author{
Wa Ode Nisrawati* \\ Diponegoro University, Jalan Prof. Sudharto, S.H., Tembalang, Semarang, Indonesia
}

\begin{abstract}
A B S T R A C T
The objective of this research was to find out the Islamic Economics students' needs and wants in learning English at State Islamic University of Pekalongan. The researcher used questionnaire to investigate and elicit opinion related to the needs, demands for English skills and preference of English learning activities, difficulties and barriers encountered by the students in learning English. The result reveals that most students show high demand on the speaking skill and want to develop it more. Besides, this research reveals that the students are facing difficulties and problems in communication because of the lacks of vocabulary, speaking skill, and grammar. Considering this result, it is suggested that the instructor/lecturer needs to give more input of vocabularies especially vocabularies related to students' major and occupational purposes.
\end{abstract}

A R T I C L E I N F O

Paper Type:

Research Article

Article History:

Received 25 September 2018

Revised 24 October 2018

Accepted 25 October 2018

Keywords:

- Needs analysis

- learning preference

- Islamic economics students

\section{Introduction}

The status of English as an international language has affected many areas in our life. Related to its status, English becomes a dominant and required language in certain fields, especially in science and education. The increase of needs toward English gives an effect to the policy about learning English at university level. English subject becomes one of the $M K D U$ or general basic courses in the university to prepare the students with sufficient proficiency that can be implemented at their work place in the future.

English as a part of general basic courses at university level may give better preparation for students in their occupational fields. The objective of English as general basic course then leads us to the question whether the English material will always be the same for all majors or not. The answer is, it has to be different based on the focus of their major. That is why we need an approach to fulfill their needs in English called as ESP (English for Specific Purposes), a teaching approach that emphasizes on the contents and methods based on the learners' needs.

ESP is actually aimed to give students knowledge and skills of English language related to their major or specialization and emphasizes the relevant principle. That is why the course needs to be appropriate with the students' needs. Besides, English for Specific Purposes (ESP) is different from English for General Purposes (EGP) in terms of the course design.

One of the ways to assess the students' needs is by conducting a Needs Analysis to them. This way seems appropriate since in designing the curriculum, the stakeholder needs to discover learners' needs and wants. It is also important for the stakeholder to enhance learners' motivation, to improve their English language competency and skills and to meet their specific needs. The syllabus, the teaching techniques and the activities in the classrooms need be related to the English where the students will come across in their specific studies in the college and in their target careers in Islamic Economic field.

\footnotetext{
*E-mail Addresses: ainisnisra@gmail.com 
There have been some previous studies concerning needs analysis. First, Miyake \& Tremarco (2005) did research on the needs of undergraduate, postgraduate and professional nurses and the aims was to find out the balance between social and technical English in terms of syllabus design, classroom activities and professional requirements. The result showed that social English is more necessary than technical English and it also suggested that classroom activities should emphasize the social communicative purposes. Second, Hossain (2013) investigated the needs and wants required by engineering students. The result indicated that the materials selection should be varied in terms of content to train people for a job, serving material used in a job and other materials relevant to occupational purposes. Third, Lee (2016) investigated the learners' perspective about their needs in ESP course. The result showed that the most needed skill is writing skill.

\subsection{ESP}

Hutchinson \& Waters (1987) define ESP or English for Specific Purpose as an approach in English language teaching that emphasizes on the learners' needs. Based on this definition, ESP is designed with an objective to fulfill the needs of students toward language they learn. Besides, it has a function to ensure the learning process and implementation is relevant and agrees with the learners' needs.

In addition, Blackie (1979) also elaborated the meaning of ESP as a learning program designed for groups of learners who are homogeneous with respect to aims, and whose specific learning objectives have been quantified and stated in communicative terms. The focus of this definition is homogeneity within the group of learners, in which, as Blackie (1979) explains, can be identified based on two factors: (1) general communicative competence in terms of language skills, which can be determined by a placement test, and (2) students' learning needs, which can be determined by an appropriate needs analysis.

There are several characteristics of ESP as demonstrated by Strevens (1988):

Table 2.1: Strevens' list of ESP characteristics

\begin{tabular}{|c|c|}
\hline Absolute characteristics & $\begin{array}{l}\text { Variable } \\
\text { characteristics }\end{array}$ \\
\hline Designed to fulfill learners' specific needs & $\begin{array}{l}\text { Limited as to language } \\
\text { skills to be learned (e.g., } \\
\text { speaking only) }\end{array}$ \\
\hline $\begin{array}{l}\text { The content (themes and topics) is related to specific disciplines, activities and occupations } \\
\text { Focused on language appropriate to those activities } \\
\text { It is in contrast with GE (General English) }\end{array}$ & $\begin{array}{l}\text { Not taught based on } \\
\text { pre-ordained } \\
\text { methodology }\end{array}$ \\
\hline
\end{tabular}

\subsection{Language needs analysis}

According to West (1994), the term "analysis of needs" first was used in the 1920's in India when Michael West introduced the concept of needs to seek what learners have to do with the foreign language and how learners master the language during the period learning. Talking about the focus of needs analysis, Hutchinson \& Waters (1987) have divided it into target needs that focuses on what learners need to do in target situation and learning needs that focuses on what learners need to do in order to learn. This present study focuses on target needs. The target needs are also divided into three types of needs:

(1) Necessities: things that learners are required to do in target learning

(2) Wants: things that the learners wish to learn. Learners also have their own views about what they think important and useful for them

(3) Lacks: it is about how good the learners are at this present situation. It has a function to see what the learners' lack or difficulty in their learning

After summarizing and reviewing theories and previous studies, by taking a case in Islamic Economics studies major at State Islamic University of Pekalongan, the researcher could propose the research problem as follows:

(1) Does the material/syllabus design meet the perceived needs of the students?

(2) What are the actual needs and wants of students in their English course? 


\section{Research Methods}

By implementing purposive sampling, this research involved 41 students of Islamic Economics IAIN Pekalongan who were in the $3^{\text {rd }}$ semester and took English III course. The researcher's consideration of choosing them as participants is that they have studied English I and English II in Islamic Economics major. The researcher used questionnaire that consists of close and open-ended questions, and the students gave their responses in written form related to their needs and wants in their English course learning.

\section{Result and Discussion}

\subsection{Students' view toward English}

Firstly, the researcher thought that it was important to find out to what extent learners to learn English. In the questionnaires delivered to the students, there was a question that asked about students' voice related to the importance of English for them in order to know if they really want to learn English or not. The students were also asked about their current reasons in learning English. The researcher found several components of the students' reasons in learning English. Those are: 1) belief that English is important due to its status as International language, 2) reason that is related to job and career in the future, 3) want that the students want to study or travel abroad, 4) English is a required course, 5) communication reason (they need to learn English in case tourist/foreigner), 6) self's pride, 7) need to pursue knowledge, 8) follow fashion, 9) interest in English

Table 4.1. Students' reasons in learning English

\begin{tabular}{ll}
\hline Students' reasons & Total of Students (Percentage) \\
\hline English is an international language & 18 students $(44 \%)$ \\
English is important for future job and career & 15 students $(37 \%)$ \\
Required course & 6 students $(15 \%)$ \\
Communication reason & 6 students $(15 \%)$ \\
Pursue knowledge & 5 students $(12 \%)$ \\
Follow trend & 4 students $(10 \%)$ \\
Self's pride & 3 students $(7 \%)$ \\
Study and travel abroad & 1 student $(2 \%)$ \\
Interested in English & 1 student $(2 \%)$ \\
\hline
\end{tabular}

This item $(\mathrm{Q} 1)$ is an open-ended question that enables students to answer freely with various answers. This question is mainly directed to investigate the students' view about the importance of English subject by mentioning their reasons of learning it. Based on the above table, we can see that there are nine reasons revealed by the students. The above table also suggests that the majority of the students considered English as an important language related to its status as an international language. Among the various answers of the students, eighteen out of forty-one students (44\%) gave answer that they had a belief that English is very important due to its status as an international language. Fifteen out of forty-one students also believed that English is very important because they will need it when they have to get a job and work for their career in the future.

"Bahasa Inggris itu penting. Karena Bahasa Inggris Bahasa Internasional dan berperan PENTING dalam DUNIA BISNIS apalagi dengan perkembangan pada zaman modern ini”"

"English is important. It is an international language and plays an important role in Business, especially in this modern era"

The above statement is one of the students' answers related to the reason of English as an international language. The students stated that, due to its status as an international language, English is then necessary for them especially in their career in business field. In the following result, the researcher shows the student's answer related to other reasons of learning English. 
"Saya belajar Bahasa Inggris karena ingin memperdalam pengetahuan saya. Selain itu Bahasa Inggris juga sangat penting dan dapat membantu kita nantinya jika kita mesti berbicara dengan orang yang berasal dari negara lain.

"I learn English because I want to deepen my knowledge. Besides, English is important and necessary for me if I get an experience to talk to the tourist in the future.

The above statement shows the reason of pursuing knowledge related to English language. That statement also shows us the communication reason of learning English. The students view English as an important language that can be used to communicate with people from other countries. It is relevant since English is the language that is worldwide spoken and has become the language of communication. There are approximately 50 countries use English as an official language and it makes English spoken worldwide (Ozaki, 2005). Besides, English is also the most popular language when it comes to business and many international organizations use it as their official language.

Furthermore, the result also shows that $7 \%$ of students also believe that they need English for their future career. They consider English may be necessary when they look for a job in the future. Besides, the above table also shows that there are $15 \%$ of the students who expressed their reason in learning English just because English is a required course. As the students expressed this statement, they have no choice but learning English to meet the obligation as a learner.

\subsection{Students' preference toward language they need (Q2)}

Table 4.2. Students' language preference

\begin{tabular}{ll}
\hline Language the students need & Percentage \\
\hline Bahasa Indonesia & $3 \%$ \\
English & $0 \%$ \\
BahasaIndonesia and English & $93 \%$ \\
\hline
\end{tabular}

Teaching English for Islamic studies in Indonesia must be complicated since the instructors do not only need to consider two languages (Bahasa Indonesia and English), but also three languages (Bahasa Indonesia, English and Arabic). Among the total of respondents, 93\% of them stated that both Bahasa Indonesia and English are important for them. Only $3 \%$ of students that chose Bahasa Indonesia as the only language they need for their career in the future. This result proves that the students cannot deny that they need both Bahasa Indonesia as their official language and English as an international language that is worldwide spoken. There is no student that choose English as the only important language to learn. On the other hand, some students added Arabic as a language they need in Islamic Economics since it is strongly related to their job field.

\subsection{Students' needs related to their language skill preference}

Q3 and Q4 in the instrument respectively asked about language skill that lecturer stresses to and language skill that the students really want to learn in their learning process. In Q3, the students were asked to mention the skills that their instructor or lecturer emphasizes more. In Q4, the students were asked to judge the important skills they need to improve in learning English. In answering these two items, the students can give more than one answer (more than one skill: speaking, writing, reading, and listening). The students' responses are summarized in the following diagrams. 


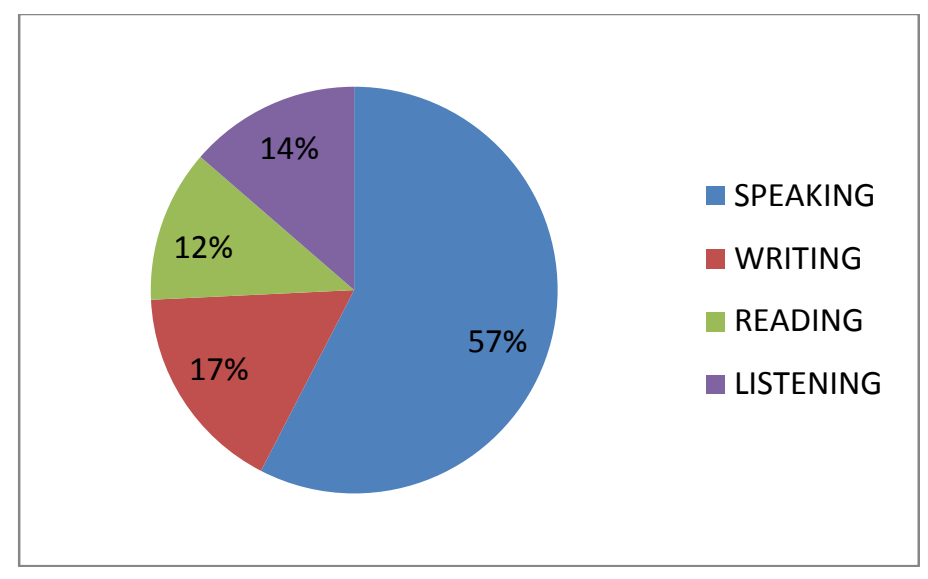

Diagram 1: Q3 Skills that Lecturer emphasizes on

The above diagram displays the skills that lecturer emphasizes based on the students' point of view. From the students' answers, the researcher finds that speaking skill has the highest percentage of the four skills. 57\% of the answers show that the lecturer emphasized the speaking skill, followed by writing, listening and reading skill that has percentage of 17\%, 14\%, and 12\% respectively. Actually, all the English skills are important and have their own functions. Reading and listening are receptive skills in which the students do not need to produce language. They only need to receive and understand language. Meanwhile, speaking and writing are productive skills that encourage students to be more active in order to be able to communicate and produce language. Therefore, in order to become a good communicator, one needs to be proficient in each of those four language skills.

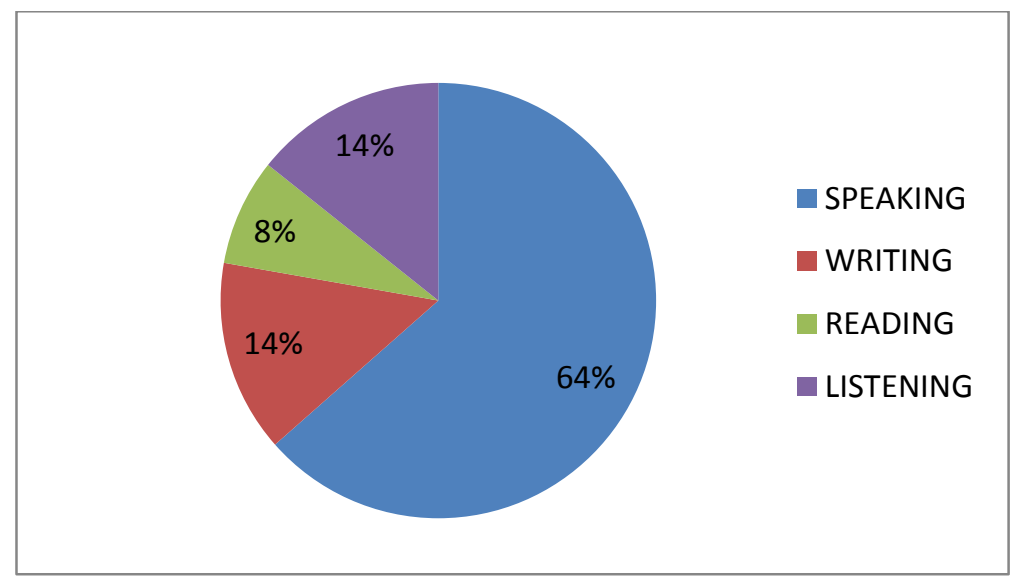

Diagram 2: Q4 Skills that the students need

The above diagram shows the students' preference toward English skills they need. They gave answer about which skill that they think the most important and they want to develop more. This is still in accordance with language skill that lecturer stresses from the students' point of view. The result shows that speaking skill becomes the first skill they want to develop (64\%), followed by writing and listening (14\%), and then reading skill $(8 \%)$.

The result shown in the above diagrams indicates a fact that the students need to emphasize their speaking skill. It makes sense since the main objective of learning certain language is related to communicative purpose. By seeing this result, the researcher hopes that the instructor/lecturer will give more attention to the speaking skill without ignoring the other skills since all skills are important in obtaining a comprehensive result of language learning. 


\subsection{Students' ability}

This item is intended to find out the students' ability from their own point of view. Due to the limited time, the researcher did not elaborate a comprehensive test to their language skills. This result was gained just by asking students to rate themselves based on the given criteria. Most of the students are still in basic ability as shown by the percentage that $73 \%$ of the students are on basic level, $24 \%$ on intermediate and only $2 \%$ of the students who rated themselves on advanced level. This result suggests that the material given to them should be appropriate to their level that they can get proper input. All students may not be at the same stages but as suggested by Krashen (1982) in one of the five hypotheses about second language acquisition, the language input should be at least beyond the current level of students' current competence. The heterogeneous class can be handled with various kinds of language teaching methods.

\subsection{Preference for learning activities}

Related to learning activities in the classroom, $76 \%$ of the students agree on the preference for working in groups or pair, meanwhile $24 \%$ of the students prefer to work alone. This indicates different preferences on learning that the lecturer/instructor must pay attention to. Among $76 \%$ of the students who agree to work with others, $81 \%$ agree to work both in pair and group, but others only agree to work in one of them. $13 \%$ of the students agree to work in pairs and 6\% only agree to work in small groups. Actually, each activity is important and meaningful for the students' development and advancement. Lecturer or instructor needs to consider learners' preference in order to create meaningful activities that make students more active, cooperative and constructive. According to Shuell (1986), every learning activity should be meaningful and the teacher's fundamental task is to get the students involved in learning activities in order to achieve the learning outcomes. Besides, Shuell added that it is helpful to remember what the students do is actually more important than what the teacher does.

\subsection{Students' needs related to their difficulties}

From 41 students, the researcher got 56 answers related to students' difficulties since it is an open- ended question so the students could freely write the difficulties they encounter in learning English. Most of students' answers $(45 \%)$ showed that vocabulary becomes the component that obtain highest percentage.

Saya kurang dalam penguasaan KOSAKATA Bahasa Inggris sehingga menyulitkan untuk mengetahui maksud apa yang disampaikan oleh dosen.

"I have difficulty in mastering English vocabulary that it makes me hard to understand what lecturer say or inform"

The second difficulty encountered by students is speaking. $21 \%$ of the answers show that students have difficulty in communicative competence especially when they have to speak in English. Even some students admitted that they do not only have difficulty in the way they speak, they even face problem in uttering English words when they were asked to speak.

Sebenarnya saya ingin belajar speaking, tetapi saya kesulitan berbicara dalam Bahasa Inggris, bahkan terkadang saya tidak tau bagaimana cara mengucapkan kata-kata tertentu yang ingin saya ungkapkan

"Actually, I want to learn speaking skill but I have difficulty when I have to talk in English, even I don't know how to say some English words"

The next problems encountered by students are grammar (14\%), learning material (11\%) and other difficulties (9\%). Other difficulties deal with writing in English, internal difficulties such as not focusing, not believing in their own ability, the classroom situation, etc. Those kinds of difficulties can be a consideration for the lecturer or instructor in organizing and carrying out the learning process.

From the above findings, the researcher could say that English is an important language to learn for most of the students because of various reasons. Though some students view English just as a required course, but most of them realize that English language is very important to learn. Besides, this research also provides a result 
about students' wants related to the skill they want to develop further and their needs related to their current ability, preference for learning activities and needs related to their difficulties.

For media, the instructors and university have provided some materials in the form of a course book. There was only one course book prepared by the university and every instructor needs to adapt the material and modify it based on the students' needs entitled FREEWAY: An EFL Course for Communication. Generally, based on what the researcher found, the course book from the university has been designed to fulfill learners' needs related to only general English. The instructor/lecturer then needs to adapt material from that book and modify the material to be relevant with Islamic studies. The instructor then has to consider the students' needs related to the things and vocabularies may be necessary for students' occupation in the future. In relation with the content, they also provided the theme and topics that were related to the Islamic economic discipline. This result indicated that it is in accordance with Streven's list about the absolute characteristics of ESP. Streven (1988) stated that an ESP needs to fulfill the learners' specific needs, the contents (theme and topics) provided have to be appropriate with the learners' major and it needs to be different from the General English.

However, the lecturer or instructor considered English for Specific Purposes (ESP) is not something obligatory to learn since the major of students is Islamic economics that need to emphasize economic and Islamic things. That is why even in the course book, the writer still put Arabic terms that were related to Islamic Economy major. Despite the existence of Arabic that is more important than English in Islamic Economy, most of the students and the English instructor/lecturer state that English is also necessary to the learners for the preparation to face the global development. The learners also state that they may need English in their career in the future. In relation to their progression in English, most of the students also stated that their English ability has improved after attending English class.

\section{Conclusion and Suggestions}

This research ensures that Islamic Economics students believe that English is important for them for various reasons such as its importance for their job and career, self's pride, pursuing knowledge, communicative purposes, fulfilling their obligation in taking English class as a required course, etc. Considering the result of this research, the students still have lot difficulties encountered in learning English especially in vocabulary, speaking and grammar. The students need more input especially in vocabulary related to their major and future career. In learning preference related to classroom activities, most of the students agree to work in group and pair. Besides, this research ensures that activities that promote confidence in communicative purpose are very essential for the students since they have a high demand on speaking skill among four language skills. In relation with the learners' needs and wants, even if it is not an urgent thing, the writer thinks that the instructor/lecturer or stakeholder need to periodically investigate learners' necessity, wants and lacks in order to provide more appropriate materials. Besides, as it concerns Islamic Economics, the English material should relate to the Islamic values in Economics field.

However, due to the limited time, this research may also face lacks and limitation especially in obtaining the data for students' ability and difficulty related to their skills. It needs to be elaborated more by giving a proper and comprehensive test to find out the students' level of ability in English.

\section{References}

Blackie, D. J. (1979). Towards a Definition of ESP. ELT Journal, XXXIII(4), 262-266. doi:https://doi.org/10.1093/elt/XXXIII.4.262

Hossain, M. J. (2013). ESP Needs Analysis for Engineering Students: A Learner Centered Approach. Journal of PU, Part: B, 2(2), 16-26.

Hutchinson, T., \& Waters, A. (1987). English for Specific Purposes. Cambridge: CUP.

Krashen, S. D. (1982). Principles and Practice in Second Language Acquisition. California: Pergamon Press Inc.

Lee, C.-L. (2016). Principles and Practices of ESP Course Design-A Case Study of a University of Science and Technology. International Journal of Learning, Teaching and Educational Research, 15(2), 94105. Retrieved from https://www.ijlter.org/index.php/ijlter/article/view/564 
Miyake, M., \& Tremarco, J. (2005). Needs Analysis for Nursing Students Utilizing Questionnaires and Interview. Kawasaki Journal of Medical Welfare, 11(1), 23-34. Retrieved from http://www.kawasakim.ac.jp/soc/mw/journal/en/2005-e11-1/03_miyake.pdf

Ozaki, T. (2005). A Study of Advocacy of Making English the Official Language. Kansai University for Foreign Language Education, 4, 11-21.

Shuell, T. J. (1986). Cognitive Conceptions of Learning. Review of Educational Research, 56(4), 411-436. doi:https://doi.org/10.3102\%2F00346543056004411

Strevens, P. (1988). ESP after twenty years: A re-appraisal. In M. Tickoo (ed), ESP: State of the art (pp. 113). SIngapore: SEAMEO Regional Language Center.

West, R. (1994). Needs analysis in language teaching. Language Teaching, 27(1), 1-19. doi:https://doi.org/10.1017/S0261444800007527 